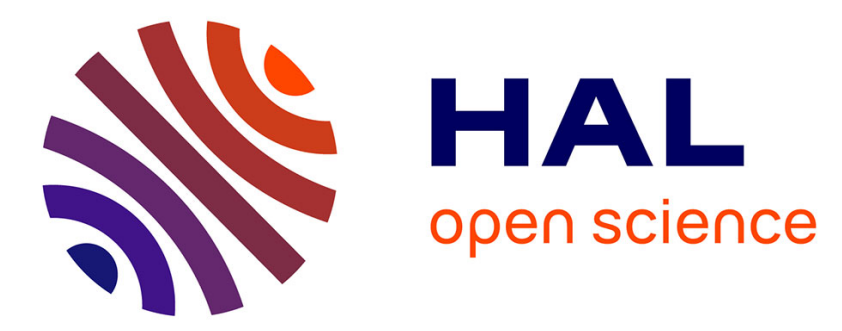

\title{
Casein in the place of beef liver in artificial diets for common carp (Cyprinus carpio L.) larvae
}

M. Szlaminska, Anne-Marie Escaffre, Hélène Alami-Durante, N. Charlon, Pierre Bergot

\section{- To cite this version:}

M. Szlaminska, Anne-Marie Escaffre, Hélène Alami-Durante, N. Charlon, Pierre Bergot. Casein in the place of beef liver in artificial diets for common carp (Cyprinus carpio L.) larvae. Aquatic Living Resources, 1990, 3 (3), pp.229-234. hal-02704922

\section{HAL Id: hal-02704922 \\ https://hal.inrae.fr/hal-02704922}

Submitted on 1 Jun 2020

HAL is a multi-disciplinary open access archive for the deposit and dissemination of scientific research documents, whether they are published or not. The documents may come from teaching and research institutions in France or abroad, or from public or private research centers.
L'archive ouverte pluridisciplinaire $\mathbf{H A L}$, est destinée au dépôt et à la diffusion de documents scientifiques de niveau recherche, publiés ou non, émanant des établissements d'enseignement et de recherche français ou étrangers, des laboratoires publics ou privés. 


\title{
Casein in the place of beef liver in artificial diets for common carp (Cyprinus carpio L.) larvae
}

\author{
Małgorzata Szlamińska (1), Anne-Marie Escaffre, Hélène $\Lambda$ lami-Durante, \\ Nicolc Charlon and Pierre Bergot \\ INRA, Station d'Hydrobiologie, Unilé d'élevage larvaire, P.I'. 3, SA.3Io Saint-Pée-sur-jivelle, France. \\ (1) Prescnt addrcss: Department of Ecological Bioenergetics, Institute of Licology, Pol. Acad. Sit, Dziekanów Lesny, 05-132 Eomianki, \\ Poland. \\ Received April 6, 1990; accepted Junc 19, r9go.
}

Szlamińska M., A.-M. Escaffre, H. Alami-Durante, N. Charlon, P. Bergot. Aquat. Living Resmur., 1990, 3, 229-234.

Abstract

Common carp larvae were fed artificial diets over 28 days at about $24^{\circ} \mathrm{C}$. Diets werc based on yeast and either beef liver or casein. Survival rates of larvae were $76-92 \%$ with liver diets and $87-96 \%$ with casein diets. Larval growth was superior with liver dicts (mean final weights $720-880 \mathrm{mg}$ ) than with casein diets $(130-340 \mathrm{mg})$. Within-tank coefficient of variation of body weight increased with mean weight according to a generalized $S$-shaped curve. The skewncss cocfficient tended to increase with the mean weight, with higher values in the cascin-fed group than in the liver-fed group. It is concluded that liver is not strictly indispensable for carp larvae diets and may be replaced by less complex components.

Keywords : Cyprinus carpio, larva, artificial diet, survival, growth, population structure.

Remplacement du foie de bouf par de la caséine dans les aliments artificiels pour les larves de carpe commune (Cyprinus carpio L.).

Résumé

Des larves de carpe commune ont été élevées avec des aliments artiliciels pendant 28 jours à environ $24^{\circ} \mathrm{C}$. Les aliments contenaient soit du foie et de la levurc, soit de la caséine à la place du foie. La survic variait de 76 à $92 \%$ avec les régimes contenant du foie et de 87 à $96 \%$ avec les régimes à base de caséine. La croissance ćtait meilleure avec le foie (poids moyen final: $720-880 \mathrm{mg}$ ) qu'avec la caséine (130-340 mg). Lc coefficient de variation intra-lot du poids des poissons augmentait avec le poids moyen des lots suivant une courbe en $\mathrm{S}$, similaire pour les deux types d'aliments. Le coefficient d'asymétrie avait tendance à augmenter avec le poids moyen et était plus élevé avec la caséine qu'avec le foic. On a conclu que le foie donnait de très bons résultats pour l'élevage des larves mais qu'il n'était pas indispensable et pouvait être remplacć par des matières premières moins complexes.

Mots-clés : Cyprinus carpio, larve, régime artiliciel, survic, croissance, structure de population. 


\section{INTRODUCTION}

The availability of semi-synthetic diets would be of extreme value in the study of nutritional requirements of young fish larvae, as they have been with juvenile fish, for instance in common carp (Murai et al., 1984). Until now purified diets have led to high mortalities and very low growth rates in carp larvae weighing $1 \mathrm{mg}$ (Sen et al., 1978). The difficulty in feeding fish larvae on purified diets has also been discussed by Dabrowski (1986).

In the present work, partial replacement of complex dietary components by purified ones was undertaken as an initial step towards the development of semisynthetic larval test diets. Feeds based on yeast and beef liver, which are known to provide good survival and growth rates in carp larvae (Charlon et al, 1986), were compared with diets containing casein instead of liver.

Beside survival and growth, stages of devclopment related to morphological criteria (Kamler et al., 1987) were examined. Parameters describing the within-tank distribution of individual larval weights, such as the coefficient of variation and the coefficient of skewness, were also taken into account. These parameters add useful information for interpretation of mean values (Backiel, 1986). In some cases, they were related to the nutritional state of larval populations. According to Rösch (1989), small values in the coefficient of variation are associated with good quality foodstuffs in coregonid larvae. Whereas, according to Nakamura and Kasahara (1977), high values of skewness coefficient reflect inadequate food supply and a situation of competition in carp larvae.

\section{MATERIAL AND METHODS}

Breeders from Donzacq experimental fish farm (Landes, France) were transported to Saint-Pée-surNivelle and kept at $20^{\circ} \mathrm{C}$ for 25 days. Spawning was induced out of season (in November) following intraperitoneal injections of a crude extract of carp hypophyses. A single pair of breeders was used for the experiment. Eggs were incubated at $19^{\circ} \mathrm{C}$. Sixteen groups of 400 swimming larvae were randomly taken from the main hatch. Experiments lasted 28 days following first exogenous feeding ( 3 days after hatching). Initial mean larval wet weight was about $1.3 \mathrm{mg}$. Larvae were reared in a semirecirculating water system as described in Charlon and Bergot (1984) but with larger rearing tanks (internal tank volume: $\left.4.5 \mathrm{dm}^{3}\right)$. Water flow rate was raised from 0.3 ( $1^{\text {st }}$ week) to $0.81 . \mathrm{min}^{-1} \cdot \operatorname{tank}^{-1}$ (last week). Water temperature was raised during a 5 day period from 19 to $24^{\circ} \mathrm{C}$ and kept constant at $24^{\circ} \mathrm{C}$ thereafter.
Seven diets and a fasted "control" group were tested in duplicate. Diets fed (table 1) varied according to their liver or casein content and the presence

Table 1. - Formulation (\%) and composition of the experimental diets (liver-diets: L, LO and LV; casein-diets: C, CO, CV and (OV).

\begin{tabular}{lrrrrrrr}
\hline \multicolumn{1}{c}{ Diets } & L & LO & LV & C & CO & CV & COV \\
\hline Liver $\left({ }^{1}\right)$ & 37 & 35 & 35 & 0 & 0 & 0 & 0 \\
Casein $\left({ }^{2}\right)$ & 0 & 0 & 0 & 37 & 35 & 35 & 33 \\
Yeast $\left({ }^{3}\right)$ & 53 & 50 & 50 & 53 & 50 & 50 & 47 \\
Mincrals $\left({ }^{4}\right)$ & 5 & 5 & 5 & 5 & 5 & 5 & 5 \\
Oil $\left({ }^{5}\right)$ & 0 & 5 & 0 & 0 & 5 & 0 & 5 \\
Vitamins $\left({ }^{6}\right)$ & 5 & 5 & 10 & 5 & 5 & 10 & 10 \\
\hline Dry matter $\left({ }^{7}\right)$ & 86 & 87 & 86 & -92 & 93 & 92 & 93 \\
N $\times 6.25\left({ }^{8}\right)$ & 54 & 52 & 52 & 67 & 64 & 63 & 63 \\
$\Lambda$ sh $\left({ }^{8}\right)$ & 10.0 & 9.6 & 9.8 & 8.8 & 8.1 & 8.9 & 8.1 \\
Energy $\left({ }^{9}\right)$ & 20.9 & 21.9 & 20.8 & 20.4 & 21.4 & 20.3 & 21.4 \\
\hline
\end{tabular}

( $\left.{ }^{1}\right)$ Beef liver (dry matter); $\left({ }^{2}\right)$ Vitamin-free casein (C-3400, Sigma); $\left({ }^{3}\right)$ Institut Français du Pétrole (France); $\left({ }^{4}\right)$ Luquet (1971); $\left({ }^{5}\right)$ Cod liver oil (Salver, France); $\left({ }^{\circ}\right)$ EIFAC (1971); $\left({ }^{7}\right) \%$ of wet weight; $\left({ }^{8}\right) \%$ of dry matter; $\left({ }^{9}\right)$ Gross energy (kJ per gof dry matter).

of cod liver oil $(0$ or $5 \%)$ and vitamins $(5$ or $10 \%)$. Food was prepared as described in Bergot et al. (1986) and delivered by automatic feed dispensers (Charlon and Bergot, 1986) between $6 \mathrm{~h}-22 \mathrm{~h}$. The size of food particles offered was $100-200 \mu \mathrm{m}$ during the 1st week, 200-400 $\mu \mathrm{m}$ during the 2 nd week and $400-630 \mu \mathrm{m}$ during the $3 \mathrm{rd}$ and $41 \mathrm{~h}$ weck. Tanks were cleaned and larval mortalities counted daily.

Samples of 70 larvae were taken from each tank weekly. After anesthetization (phenoxy ethanol), 10 live larvae were weighed (wet weight) for growth studies, 40 larvae were fixed in 4\% formaldehyde and weighed (wet weight) 6 months later to gain an approximation of weight distribution and 20 larvae were taken out for future histological observations. Larval survival was estimated using the methods of Bergot et al. (1986). WS (mean larval weight W multiplied by the survival rate $S$ ) was used as an estimation of theoretical biomass for an initial stock of 100 larvac. Developmental stages were identified in fixed larvac sampled after 14 days and the developmental index DI, i.e. the mean developmental step, was calculated according to Kamler et al. (1987). A high DI signified that larvae reach more advanced stages of development. Survival rates (after angular transformation), weights, WS (after logarithmic transformation) and DI (without transformation) were compared by variance analysis and NewmanKeuls test, by a computer assisted program (ITCF, 1988). The within-tank coefficient of variation (standard deviation as a percentage of the mean) was calculated for each sample. For the estimation of the skewness coef $\int c i i e n t(g 1)$, weight data $(x)$ were transformed in standard units $[\mathrm{X}=(x$-mean $) /$ standard 
deviation] within each tank and were pooled separately for larvae fed liver or casein-diets. The $g l$ coefficient was calculated as the mean value of $X^{3}$ for each group. Negative values of $g 1$ indicate skewness to the left while positive values indicate skewness to the right.

\section{RESUITS}

There was little discrepancy between the initial stock size and the total number of recovered larvae, mean difference being $2 \%$ of theoretical initial stock. Data relating to percent survival of carp larvae are

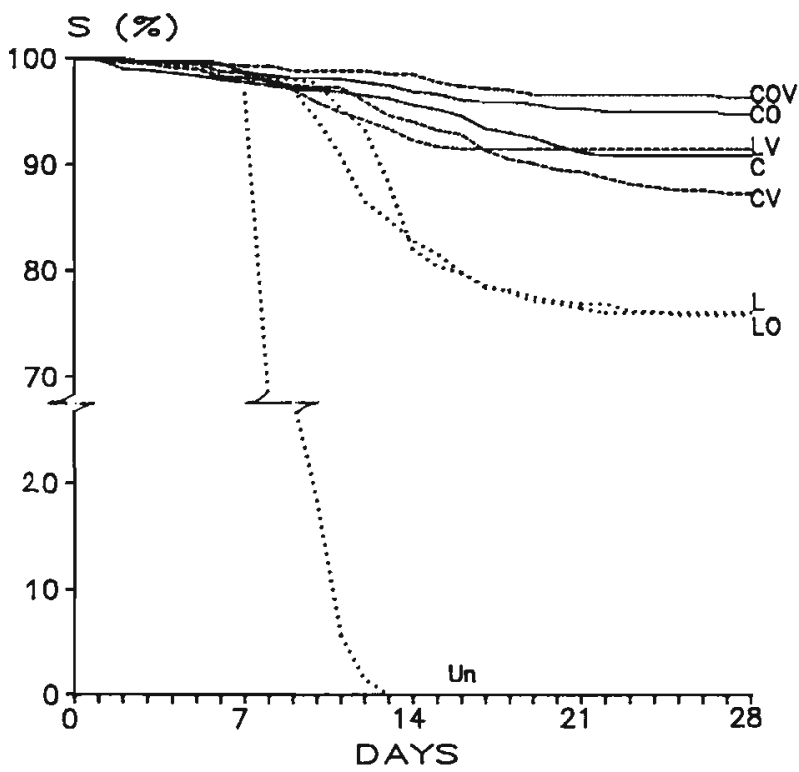

Figure 1. - Percent survival of carp larvae fed upon varjous dict formualtions. Liver-diets: LV: $-\ldots-$; L and LO: ...... Casein-diets: $\mathrm{COV}$ and $\mathrm{CV}: \cdots . .-\mathrm{CO}_{\text {and }} \mathrm{C}$ : $\longrightarrow$, Unfed: .......

shown in figure 1 and table 2. Mortality in the unfed "control" group was $70 \%$ by day 9 and by day 13 all fish had died. Survival rates of fed larvae were very high $(87-96 \%)$, with the exception of those fish fed upon $\mathrm{L}$ and $\mathrm{LO}$ diets $(76 \%)$.

As early as day 7 of the experiment, a significant effect of diet upon larval growth was observed. In particular the liver diets provided exceptional growth compared with the casein test diets (table 2). This difference was maintained throughout the experiment. Significant effects relating to dietary supplementation were evident for each group (table 2). Thus, on day 14 , significant differences were observed between the liver diets: growth being best with the LV diet and worst with the LO diet, while diet L was intermediate. Similar effects with respect to the casein groups were not observed until day 28 , when the best growth result was obtained with the COV diet and the poorest with the $\mathrm{C}$ diet.

WS (theoretical biomass) was higher with liver diets than with casein diets and, on day 14, WS was significantly higher with diet LV than with either L or LO diets while no significant difference was found between casein groups. By day 28, no difference between the liver diets was evident, but the COV and $\mathrm{CO}$ diets were significantly better than either $\mathrm{C}$ or $\mathrm{CV}$ dicts (table 2).

Two wecks into the study, DI values were greater in liver-fed groups when compared with casein-fed fish. Larvae fed LV had a greater DI than larvae fed LO (table 2).

Rations dispensed, when expressed as percent body weight per day, were higher in casein-fed than in liver-fed larvae. These rates were very high during the first week (about 200-500\%) and decreased gradually to about $10-40 \%$ during the last week (table 3 ).

The coefficient of variation of larval weights increased with mean weight according to an S-shaped curve (fig. 2). A strong increase of the coefficient of variation was observed between 5 and $20 \mathrm{mg}$. Maximal common values were about $40 \%$. Distribution of the initial sample was not significantly different from a symmetric one (fig. 3). On day 7 , negative values of $g l$ were found. For similar mean weights, the values of $g l$ were higher in the casein group than in the liver group. In both groups the skewness coefficient increased during the experiment and had positive values by day 28 .

\section{DISCUSSION}

Baranova (1974), working with zooplankton and Bryant and Matty (1980), working with Artemia nauplii, estimated that optimal daily rations for carp larvae, expressed as percentage larval wet weight, were $200-300 \%$ wet weight of food, i.e a about $20-30 \%$ dry weight. In comparison, diets in the present study with a dry matter content of about $90 \%$ were given in large excess, particularly during the first two weeks. However, significant cannibalism seemed to be excluded since the observed number of larvae and the recalculated number of larvae were similar.

Initial larval density was in the usual range when compared with other experiments upon cyprinid larvae (Szlamińska, 1988) and was decreased by weekly sampling. However, at the end of the experiment, the biomass of fish per tank was high and final growth rates were perhaps reduced with $\mathrm{LV}$ diet (biomass about $40 \mathrm{~g}$ per tank compared with $23 \mathrm{~g}$ per tank with $\mathrm{L}$ diet).

Ration particle sizes were changed simultaneously for all diets. The tanks containing the smallest larvae were perhaps at a disadvantage, for instance after the change on day 7 from $100-200$ to $200-400 \mu \mathrm{m}$ 
Table 2. - Survival (S), mean wet weight (W), weight survival (WS) and developmental index (DI) after $7,14,21$ and 28 days of experiment $\left(^{*}\right)$.

\begin{tabular}{|c|c|c|c|c|c|c|c|c|}
\hline Diets & Day & $\mathrm{L}$ & LO & LV & c & $\mathrm{CO}$ & $\mathrm{CV}$ & $\mathrm{COV}$ \\
\hline \multirow[t]{4}{*}{$S(\%)$} & 7 & 99 & $\begin{array}{r}99 \\
a\end{array}$ & $\begin{array}{r}99 \\
\text { a }\end{array}$ & 98 & $\begin{array}{r}99 \\
a\end{array}$ & 98 & $\begin{array}{r}99 \\
a\end{array}$ \\
\hline & 14 & $\begin{array}{c}83 \\
b\end{array}$ & $\begin{array}{c}82 \\
b\end{array}$ & $\begin{array}{c}92 \\
a\end{array}$ & $\begin{array}{c}96 \\
a\end{array}$ & $\begin{array}{c}97 \\
6\end{array}$ & $\begin{array}{c}94 \\
a\end{array}$ & $\underset{a}{98}$ \\
\hline & 21 & $\begin{array}{c}77 \\
b\end{array}$ & $\begin{array}{c}77 \\
b\end{array}$ & 92 & 92 & 95 & $\begin{array}{c}90 \\
a\end{array}$ & 97 \\
\hline & 28 & $\begin{array}{c}76 \\
\mathrm{r}\end{array}$ & $\begin{array}{c}76 \\
c\end{array}$ & 92 & $\begin{array}{c}91 \\
a b\end{array}$ & $\begin{array}{c}95 \\
a b\end{array}$ & $\begin{array}{r}87 \\
b\end{array}$ & $\begin{array}{r}96 \\
a\end{array}$ \\
\hline \multirow[t]{4}{*}{ W (mg) } & 7 & $\begin{array}{l}6.9 \\
0\end{array}$ & 7.1 & $\begin{array}{l}8.1 \\
a\end{array}$ & $\begin{array}{l}4.9 \\
b c\end{array}$ & $\begin{array}{l}4.8 \\
e^{2}\end{array}$ & 4.8 & $\underset{a b c}{5.3}$ \\
\hline & 14 & $\begin{array}{c}42 \\
b\end{array}$ & $\begin{array}{c}35 \\
c\end{array}$ & $\begin{array}{c}59 \\
a\end{array}$ & $\begin{array}{r}13 \\
d\end{array}$ & 13 & $\frac{13}{d}$ & $\begin{array}{c}16 \\
d\end{array}$ \\
\hline & 21 & 213 & $\begin{array}{r}198 \\
a\end{array}$ & $\begin{array}{r}262 \\
a\end{array}$ & $\begin{array}{c}44 \\
h\end{array}$ & $\begin{array}{c}70 \\
b\end{array}$ & $\begin{array}{c}50) \\
b\end{array}$ & $\begin{array}{c}83 \\
b\end{array}$ \\
\hline & 28 & $\begin{array}{r}884 \\
4\end{array}$ & $\begin{array}{c}690 \\
a\end{array}$ & $\underset{a}{721}$ & 135 & $\underset{b}{321}$ & $\underset{b}{213}$ & $\begin{array}{c}342 \\
b\end{array}$ \\
\hline \multirow[t]{4}{*}{ WS (g) } & 7 & $\begin{array}{l}0.7 \\
a\end{array}$ & $\begin{array}{l}0.7 \\
a\end{array}$ & $\begin{array}{c}0.8 \\
.\end{array}$ & $\begin{array}{c}0.5 \\
6\end{array}$ & 0.5 & $\begin{array}{l}0.5 \\
b\end{array}$ & $\begin{array}{c}0.5 \\
b\end{array}$ \\
\hline & 14 & $\begin{array}{l}3.5 \\
b\end{array}$ & $\begin{array}{c}2.9 \\
b\end{array}$ & $\begin{array}{l}5.4 \\
a\end{array}$ & $\begin{array}{l}1.2 \\
c\end{array}$ & $\begin{array}{l}1.2 \\
c\end{array}$ & $\begin{array}{l}1.2 \\
c\end{array}$ & $\begin{array}{l}1.5 \\
c\end{array}$ \\
\hline & 21 & $\begin{array}{c}16.4 \\
b\end{array}$ & $\begin{array}{c}15.1 \\
b\end{array}$ & $\begin{array}{c}24.0 \\
a\end{array}$ & $\begin{array}{l}4.0 \\
d\end{array}$ & $\begin{array}{l}6.6 \\
6\end{array}$ & $\begin{array}{l}4.5 \\
d\end{array}$ & $\begin{array}{c}8.0 \\
c\end{array}$ \\
\hline & 28 & $\begin{array}{c}67.1 \\
a\end{array}$ & $\begin{array}{c}52.4 \\
a\end{array}$ & $\begin{array}{c}66.0 \\
a\end{array}$ & $\underset{r}{12.3}$ & $\begin{array}{c}30.3 \\
0\end{array}$ & $\begin{array}{c}18.6 \\
6\end{array}$ & $\begin{array}{c}33.1 \\
h\end{array}$ \\
\hline DI & 14 & $\begin{array}{l}8.5 \\
a b\end{array}$ & $\begin{array}{c}7.5 \\
b\end{array}$ & $\begin{array}{l}9.0 \\
a\end{array}$ & 5.7 & $\begin{array}{l}5.4 \\
c\end{array}$ & $\begin{array}{l}5.2 \\
c\end{array}$ & $\begin{array}{l}6.1 \\
c\end{array}$ \\
\hline
\end{tabular}

$\left(^{*}\right)$ Means of two replicate groups. Means not sharing a common superscript in each line are significantly different (diet effects are tested upon replicate effects: $p<0.05$ ).

Table 3. - Rations dispensed (expressed as percent body weight per day) for cach week of experiment.

\begin{tabular}{lrr}
\hline Diets & L & LO \\
\hline Week 1 & 328 & 290 \\
Week 2 & 91 & 71 \\
Wcck 3 & 28 & 41 \\
Week 4 & 17 & 13 \\
\hline
\end{tabular}

\begin{tabular}{rrrrr}
\cline { 2 - 4 } LV & $\mathrm{C}$ & $\mathrm{CO}$ & $\mathrm{CV}$ & $\mathrm{COV}$ \\
207 & 334 & 441 & 514 & 414 \\
48 & 320 & 230 & 178 & 182 \\
19 & 94 & 60 & 74 & 51 \\
11 & 41 & 21 & 32 & 17 \\
\hline
\end{tabular}

particles. It is possible that initial differences in growth, between and within groups, were accentuated by this effect.

Liver diets allowed high growth rates. With the best diet (dict LV), the mean live weight of fish was around $59 \mathrm{mg}$ by day 14 , corresponding to a daily weight specific growth rate (SGR) of about $29 \%$ during the 1 st and 2 nd weeks. This value is in the range of those presented by Kamler et al. (1987) for carp larvae fed live food and is higher than the SGR reported for other artificial diets.

Vitamin appeared to be a limiting factor in the yeast-liver diets since addition of the vitamin mixture to diet $\mathrm{L}$ improved larval survival and mean weight on day 14. The level of vitamin supplementation in the best diet (diet LV) was high: being five times higher than that recommended by EIFAC (1971) for salmonid alevins, this even without taking into account the vitamins supplied by the liver and yeast.

In contrast, addition of cod liver oil instead of vitamins failed to improve larval survival and had a negative effect on growth by day 14 . In a previous experiment with similar diet formulations (Durante, 1986), diet $\mathrm{L}$ was reported to be superior to diet LO in terms of survival ( 95 and $64 \%$ respectively), with similar growth (mean weight of 189 and $169 \mathrm{mg}$ after 21 days). The differences observed between these experiments could, however, be explained by variation in liver quality. Regardless, supplementation of the yeast-liver based diet with cod liver oil appeared to be without effect or even detrimental.

The use of casein rather than liver decreased growth but did not alter survival which remained very high throughout the experiment. These results indicate that the basic nutritional requirements for the carp larvae were met by the casein diets and that liver was not indispensable in the larval diet. However, requirements for optimal growth were not completely satislied by the casein diets. In contrast with liver diets, the addition of cod liver oil to casein diets had beneficial effects on growth. This might be related either to the improvement of the energy/protein ratio or to the supply of essential fatty acids (as the level of $(n-3)$ 


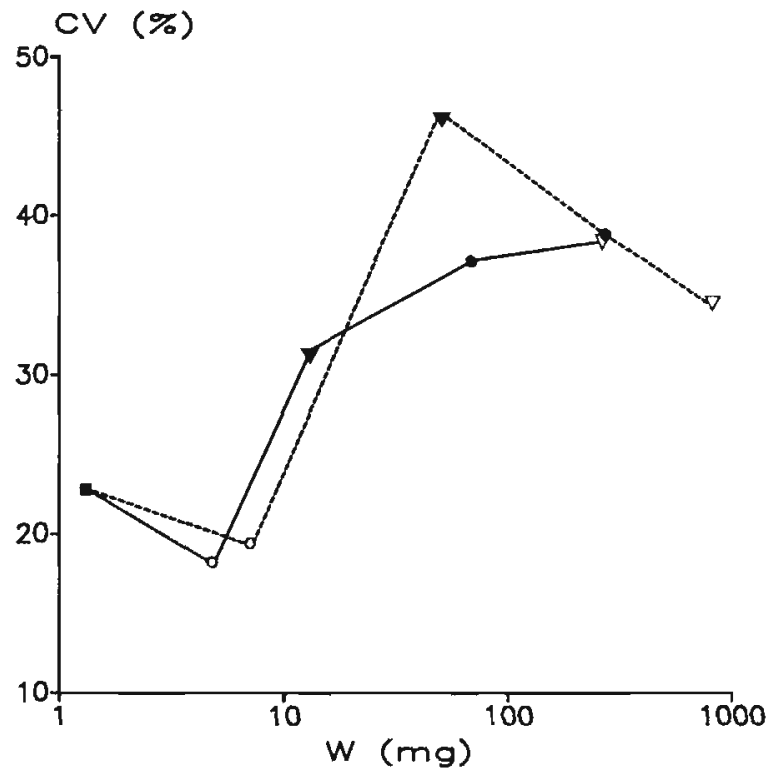

Figure 2. - Relationship between the within-tank coefficient of variation $(\mathrm{CV}, \%)$ and mean wet weight $(\mathrm{W}, \mathrm{mg})$ of carp larvae. Larvae fed liver-dicts: broken line; larvae fed casein-diets: unbroken line. Sample size: initial: $n=49$; liver group: $n=226-237$ per week; casein group: $n=300-321$ per weck. Days of experiment: day 0: $\mathbf{\square}$; day $7: 0$; day $14: \nabla$; day $21: 0$; day $28: \nabla$.

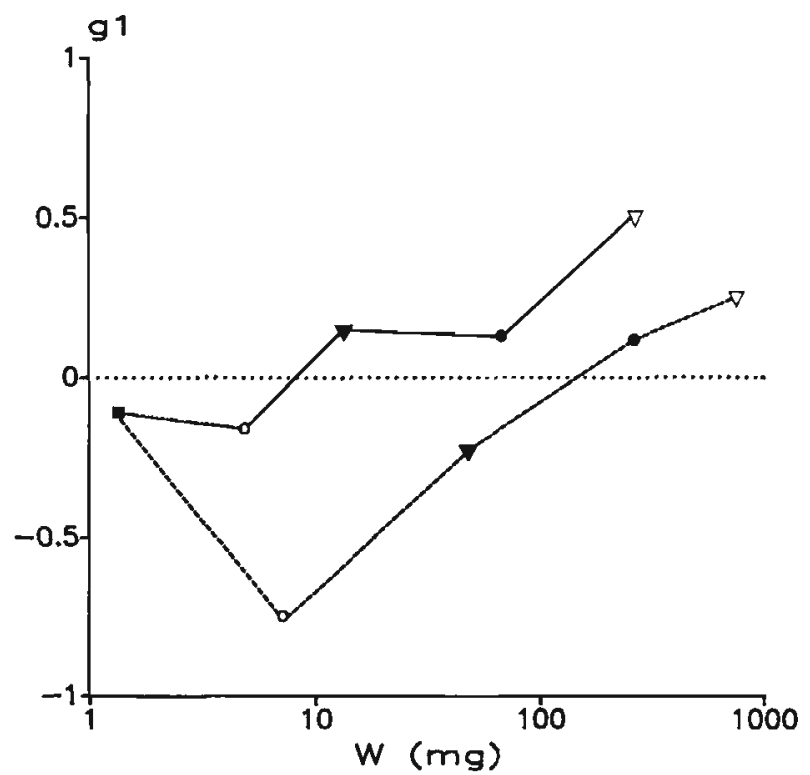

Figure 3. - Relationship between the within-tank coefficient of skewness ( $\mathrm{g} 1)$ and mean wet weight $(\mathrm{W}, \mathrm{mg})$ of carp larvae. Same symbols as in figure 2 .

fatty acids is probably low in diets $\mathrm{C}$ and $\mathrm{CV}$ ) or to the supply of liposoluble vitamins. However, vitamin supplementation did not improve growth as clearly as cod liver oil did.

In carp larvae of the same age fed different artificial diets or zooplankton, Kamler et al. (1990) found that the developmental index was higher with food more suitable for growth. They stressed that the length of fish at a given developmental stage was relatively constant and independent of the type of food ingested by larvae, but that differences could exist in juveniles. In the present experiment, on day 14, the developmental index was in conformity with the larval mean weight. This suggests that delayed growth was associated with a simultaneous retardation of the development and that the larvae fed casein diets were normal.

In rainbow trout, Chevassus (1976) studied the variability of wet weight within groups of full-sibs. $\mathrm{He}$ described the initial change of the coefficient of variation as an $S$-shaped curve with a maximum value of about $40 \%$, for an alevin wet weight of around $2 \mathrm{~g}$, followed by a slight decrease thereafter. Similar variation of the coefficient of variation was found for carp larvac in the present experiment, with a different weight scale.

Rösch (1989) found that the coefficient of variation of dry weight of coregonid larvac was usually higher in groups fed artificial diets (range 10-17\%) than in groups fed zooplankton (range 5-14\%). The results of the present study failed to show such differences in the coefficient of variation between groups fed casein and liver diets.

Nakamura and Kasahara (1977) reported negatively skewed distribution of body length in carp larvae after hatching. Previous works indicate symetric initial distributions in trout alevin (Chevassus, 1976) and carp (Szlaminska, 1987) with respect to body weight, which is in accord with the results of the present study. The tendency of length and weight $g 1$ to increase during growth appears as a general phenomenon in plants and animals (Uchmański, 1985). In the present experiment, an initial decrease of $g 1$ was observed, especially in groups fed liver diets. This was probably due to the presence of small larvae which were non-feeding or suffering from a metabolic disorder. The mortality observed during the second week probably concerned these larvae and their disappearance could explain the return to a symmetric aldistribution. The general increase of $g 1$ was related by most authors to competition or to deteriorating conditions of life. In the present case, $g 1$ increased to positive values in spite of apparent excess of food and suitable rearing conditions. Differences between individuals in the capacity to utilize food, possibly of genetic origin (Backiel, 1986; Szlaminska, 1987) could explain the differentiation of the population, with an increased advantage for bigger fish over the smaller when food is less suitable.

In conclusion, liver ensures high growth rates and is an useful feedstuff in practical diets for carp larvae. But it is not indispensable. Casein could be useful in 
experimental diets directed towards the determination of nutritional requirements. This aim still requires the replacement of yeast by purified ingredients.

\section{Acknowledgements}

We thank Mrs P. Peyrotte for the preparation and analysis of diets.

\section{REFERENCES}

Backiel T., 1986. Masking cffects of variability of growth on its estimation in juvenile tench, Tinca tinca (L.) reared at different temperatures. Pol. Arch. Hydrohiol., 33, 69-95.

Baranova V. P., 1974. Dependence of the carp larvac growth rate on conditions of rcaring. Jzz. Gos. NauchnoIssled. Inst. Ozern. Rechn. Rybn. Khoz., 92, 66-78 (in Russian).

Bergot P., N. Charlon, H. Durante, 1986. The cffect of compound diets feeding on growth and survival of coregonid larvae. Arch. Hydrobiol. Beih. Ergebn. Limnol., 22, 265-272.

Bryant P. I., A. J. Matty, 1980. Optimisation of Artemia feeding rate for carp larvac (Cyprinus carpio L.). Aquaculture, 21, 203-212.

Charlon N., P. Bergot, 1984. Rearing system for feeding fish larvac on dry diets. Trial with carp (Cyprinus carpio L.) larvac. Aquaculture, 41, 1-9.

-, 1986. An improved automatic dry food dispenser for fish larvae. Prog. Fish-Cult., 48, 156-158.

Charlon N., H. Durante, A. M. Escaffre, P. Bergot, 1986. Alimentation artificicllc des larves de carpe (Cyprinus carpio L.). Aquaculture, 54, 83-88.

Chevassus B., 1976. Variabilité et héritabilité des performances de croissance chez la truite arc-en-ciel (Salmo gairdneri Richardson). Ann. Génét. Sél. Anim., 8, 273-283.

Dabrowski K. R., 1986. Ontogenctical aspects of nutritional requirements in Fish. Comp. Biochem. Physiol., 85 A, 639655.

Durante H., 1986. Influence de l'alimentation sur la croissance des larves de carpe (Cyprinus carpio) et de corégone (Coregonus schinzi palea). Aspects morphologiques. Thèse dr. $3^{\mathrm{e}}$ cycle, Univ. Bordeaux I, $173 \mathrm{p}$.

EIFAC, 1971. Salmon and trout feeds and feeding. EIFAC Tech. Pap., 12, 29 p.
ITCF, 1988. Stat ITCF. $4^{e}$ édition. Service des F́tudes Statistiques, Paris.

Kamler E., E. Urban-Jczicrska, I. A. Stanny, M. I ewkowicz, S. Lewkowicz, 1987. Survival, development, growth, metabolism and feeding of carp larvac receiving zooplankton or starters. Pol. Arch. Hydrobiol, 94, 503541 .

Kamler E., M. Szlamińska, A. Prıybyl, B. Barska, M. Jakubas, M. Kuczyński, K. Raciborski, 1990. Developmental response of carp, Cyprinus carpio L., larvae fed different foods or starved. Entiron. Biol. Fish. (in press).

Luquet P., 1971. Efficacité des protéines en relation avec leur taux d'incorporation dans l'alimentation de la truite arc-en-ciel. Ann. Hydrohiol., 2, 175-186.

Murai T., T. Akiyama, T. Nose, 1984. Effect of the amino acid balance on efficiency in utilization of diet by fingerling carp. Bull. Jpn. Soc. Sci. Fish., 50, 893-897.

Nakamura N., S. Kasahara, 1977. A study of the phenomenon of the Tobi-Koi or shoot carp. Badmigeh, 29, $41-47$.

Rösch R., 1989. Coefficient of variation of linal length as indicator of the quality of starter dicts for fish larvae. Spec. Publ. Eur. Aquacult. Soc, 10, 221-222.

Sen P. R., N. G. S. Rao, S. R. Ghosh, M. Rout, 1978. Observations on the protein and carbohydrate requirements of carps. Aquaculture, 13, 245-255.

S7lamińska M., 1987. Survival, growth and size structure of carp (Cyprinus carpio L.) larvac populations fed dry fced Ewos larvstart C-10 or zooplankton or else starved. Pol. Arch. IJydrotiol., 34, 331-346.

$-\cdots$ 1988. A review of studies on Cyprinid fish rearing in artificial conditions. Roczn. Nauk Roln., 101, 87-109 (in Polish).

Uchmański J., 1985. Differentiation and frequency disiributions of body weights in plants and animals. Phil. Trans. R. Soc. Lond., B 310, 1-75. 